Discussion Paper No. 13-030

Do Horizontal Mergers Induce Entry? Evidence from the U.S. Airline Industry

Patrice Bougette, Kai Hüschelrath, and Kathrin Müller

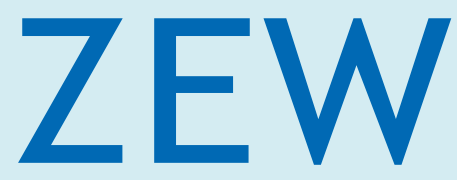

Zentrum für Europäische Wirtschaftsforschung $\mathrm{GmbH}$ Centre for European Economic Research 
Discussion Paper No. 13-030

\title{
Do Horizontal Mergers Induce Entry? Evidence from the U.S. Airline Industry
}

\author{
Patrice Bougette, Kai Hüschelrath, \\ and Kathrin Müller
}

Download this ZEW Discussion Paper from our ftp server:

http://ftp.zew.de/pub/zew-docs/dp/dp13030.pdf

Die Discussion Papers dienen einer möglichst schnellen Verbreitung von neueren Forschungsarbeiten des ZEW. Die Beiträge liegen in alleiniger Verantwortung der Autoren und stellen nicht notwendigerweise die Meinung des ZEW dar.

Discussion Papers are intended to make results of ZEW research promptly available to other economists in order to encourage discussion and suggestions for revisions. The authors are solely responsible for the contents which do not necessarily represent the opinion of the ZEW. 


\section{Non-technical summary}

Merger control has become an important part of antitrust policy in many countries around the world. In an ex-ante assessment of horizontal mergers, antitrust authorities typically have to investigate whether the proposed transaction is likely to lead to a substantial lessening of competition. While the merger as such inevitably leads to an increase in market concentration and is therefore susceptible of increasing both market power and market prices, there are two general countervailing forces: demand-side substitution and supply-side substitution. Demand-side substitution basically refers to the degree consumers would switch to substitutes in case of a price increase post-merger while supply-side substitution assesses whether and how competitors will react to such price increases.

In this note, we contribute to the sparse empirical literature on supply-side reactions to a merger, i.e., we investigate whether competitors increase or decrease their entry activity in the aftermath of an increase in market concentration through merger. In particular, we use routelevel data for the America West Airlines - US Airways merger (2005) to investigate whether such an effect can be identified empirically. Our results show that both entry-inducing and entry-dissuading effects can be observed depending on the type of affected route and the carrier under investigation. Interestingly, routes with ex-ante greater competition concerns (i.e., routes in which both merging parties competed directly before the merger) do not show increased entry activity. Our results therefore suggest that entry-inducing effects should be treated with caution in merger assessments by competition authorities thereby supporting the key policy conclusions derived in Werden and Froeb (1998) from a theoretical perspective. 


\section{Das Wichtigste in Kürze}

In vielen Ländern der Welt ist die Fusionskontrolle zu einem integralen Bestandteil der Wettbewerbspolitik geworden. Im Rahmen einer ex-ante Untersuchung von horizontalen Fusionsvorhaben untersuchen Wettbewerbsbehörden regelmäßig, ob der geplante Zusammenschluss zu einer wesentlichen Verringerung des Wettbewerbs führt. Während eine horizontale Fusion unweigerlich eine Erhöhung der Marktkonzentration zur Folge hat und damit im Verdacht steht, die Marktmacht der fusionierenden Partei zu erhöhen, existieren zwei Effekte die etwaigen Preissteigerungsanreizen entgegenwirken: nachfrageseitige Substitution und angebotsseitige Substitution. Nachfrageseitige Substitution bezieht sich auf den Anteil an Konsumenten, der im Falle einer Preiserhöhung zu Wettbewerbern wechseln würde, während angebotsseitige Substitution die Frage untersucht, in welchem Ausmaß Wettbewerber auf fusionsbedingte Preiserhöhungen reagieren würden.

Mit diesem Kurzbeitrag tragen wir zu der spärlichen empirischen Literatur bei, die sich einer Untersuchung der angebotsseitigen Reaktionen auf eine horizontale Fusion widmet; das heißt, wir gehen der Frage nach, ob Wettbewerber ihre Markteintrittsaktivitäten nach erfolgter Fusion erhöhen oder senken. Konkret nutzen wir Marktdaten auf Streckenebene nach dem Abschluss der America West Airlines - US Airways Fusion (2005) um zu untersuchen ob empirische Belege für eine entsprechende Reaktion der Wettbewerber gefunden werden können. Unsere Ergebnisse zeigen, dass sowohl verstärkter Markteintritt als auch reduzierter Markteintritt in der Folge der Fusion beobachtet werden konnten und zwar in Abhängigkeit vom Routentyp und der betrachteten Fluggesellschaft. Interessanterweise zeigt sich weiterhin, dass Streckenmärkte mit ex-ante höherem Preissteigerungspotential - das heißt insbesondere Streckenmärkte auf denen die beiden fusionierten Parteien in direktem Wettbewerb standen keine erhöhten Markteintrittsaktivitäten aufweisen. Unsere Ergebnisse legen daher den Schluss nahe, dass Wettbewerbsbehörden im Rahmen von Fusionsuntersuchungen vorgebrachten Argumenten einer marktmachtdisziplinierenden Wirkung von Markteintritten (nach erfolgter Fusion) mit einem gehörigen Maß an Skepsis entgegentreten sollten. In dieser Hinsicht bestätigen unsere Ergebnisse die zentralen theoretischen Erkenntnisse des Beitrags von Werden und Froeb (1998). 


\title{
DO HORIZONTAL MERGERS INDUCE ENTRY? EVIDENCE FROM THE U.S. AIRLINE INDUSTRY
}

\author{
Patrice Bougette ${ }^{f}$, Kai Hüschelrath* and Kathrin Müller*
}

April 2013

\begin{abstract}
Theoretical research has investigated the relevance of entry-inducing effects as countervailing factor to a merger-related increase in market power. We use route-level data for the America West Airlines - US Airways merger (2005) to investigate whether such an effect can be identified empirically. Our results show that both entry-inducing and entry-dissuading effects can be observed depending on the type of affected route and the carrier under investigation.
\end{abstract}

Keywords Airline industry, merger, entry-inducing effects

JEL Class L40, L93

f Associate Professor, University of Nice-Sophia Antipolis, GREDEG Law, Economics and Manage-ment Research Group, CNRS UMR 7321, 250 rue Albert Einstein, 06560 Valbonne, France, E-mail: patrice.bougette@gredeg.cnrs.fr; Research Associate, LAMETA CNRS UMR 5474, University Montpellier 1.

* Head, Competition and Regulation Research Group, ZEW Centre for European Economic Research, P.O. Box 1034 43, D-68034 Mannheim, Germany, E-mail: hueschelrath@zew.de; Coordinator, MaCCI Mannheim Centre for Competition and Innovation; Assistant Professor for Industrial Organization and Competitive Strategy, WHU Otto Beisheim School of Management, Burgplatz 2, 56179 Vallendar, Germany.

* Researcher, Competition and Regulation Research Group, ZEW Centre for European Economic Research and MaCCI Mannheim Centre for Competition and Innovation, P.O. Box 1034 43, D-68034 Mannheim, Germany, E-mail: kathrin.mueller@zew.de. 


\section{INTRODUCTION}

Merger control has become an important part of antitrust policy in many countries around the world. In an ex-ante assessment of horizontal mergers, antitrust authorities typically have to investigate whether the proposed transaction is likely to lead to a substantial lessening of competition. While the merger as such inevitably leads to an increase in market concentration and is therefore susceptible of increasing both market power and market prices, there are two general countervailing forces: demand-side substitution and supply-side substitution. Demand-side substitution basically refers to the degree consumers would switch to substitutes in case of a price increase post-merger while supply-side substitution assesses whether and how competitors will react to such price increases.

In this note, we contribute to the sparse empirical literature on supply-side reactions to a merger, i.e., we investigate whether competitors increase or decrease their entry activity in the aftermath of an increase in market concentration through merger. In particular, we use routelevel data for the America West Airlines - US Airways merger (2005) to investigate whether such an effect can be identified empirically. Our results show that both entry-inducing and entry-dissuading effects can be observed depending on the type of affected route and the carrier under investigation.

\section{REVIEW OF THE LITERATURE}

Even if a merger-induced increase in market concentration is substantial, the merging parties may be unable to exercise market power as long as potential entrants swiftly enter and start producing substitutes. The potential relevance of such so-called entry-inducing effects of horizontal mergers has been discussed from a theoretical perspective in papers by Werden and Froeb (1998), Cabral (2003), Spector (2003) and Marino and Zábojník (2006). In their seminal paper, Werden and Froeb (1998) investigate the role of entry-inducing effects in antitrust policy. Based on mergers in simple Cournot and Bertrand industries, they find that firms only have an incentive to merge if (a) they expect significant efficiencies generated from the merger, or (b) they are aware of substantial entry barriers which allow them to charge supracompetitive prices post-merger. They conclude that antitrust authorities should be rather skeptical with respect to the power of entry to prevent (or reverse) anticompetitive effects of horizontal mergers. Cabral (2003) investigates the entry-inducing effects of mergers in a differentiated Bertrand model and, on the one hand, finds that the possibility of entry 
subsequent to the merger improves consumer welfare. On the other hand, he shows for the case of a merger to monopoly that post-merger consumer welfare may decrease with a larger size of merger efficiencies; basically because they decrease the probability of entry postmerger and the beneficial effect from the cost-saving passed on to consumers is too weak to overcompensate this detrimental effect on consumer welfare. Furthermore, Spector (2003) investigates the relationship between merger efficiencies and entry in a Cournot context. Interestingly, he finds that any profitable Cournot merger that fails to generate synergies inevitably decreases consumer welfare irrespective of entry conditions. He therefore concludes that such mergers should be blocked without even considering the role of postmerger entry. Last but not least, Marino \& Zábojník (2006) focus on the time dimension of entry following a merger. They show that if new entry is relatively fast, the incumbents could not merge to increase their market power. In other words, if a merger is initiated in an industry where new entry would follow relatively quickly, the merger is more likely to generate synergies. Otherwise, it would not be attempted in the first place. Interestingly, they also show that a decrease in exogenous entry costs can increase the incumbent firms' incentives to monopolize the market through horizontal merger.

\section{THE US AIRWAYS - AMERICA WEST AIRLINES MERGER}

We specifically investigate the role of entry-inducing effects following the horizontal merger between US Airways (US) and America West Airlines (HP) in the domestic U.S. airline industry completed in 2005. Although the last decade has seen a couple of mergers between U.S. airlines, several arguments suggest focusing on the HP-US transaction. First, the merger took place at a time without severe external or internal shocks such as terrorist attacks, economic recession or other larger airline mergers. Second, the networks of both carriers were truly complementary showing only four non-stop route overlaps at the time of the merger. Third, the hubs of both airlines were located quite distant from each other with Phoenix and Las Vegas in case of America West Airlines and Charlotte, Philadelphia, and Pittsburgh in case of US Airways. This characteristic, ceteris paribus, makes one-stop connections a closer substitute to non-stop connections than in cases of closely related hubs.

In sum, the merger directly affected 239 domestic airport-pairs in the domestic U.S. airline industry. In the following, we differentiate between the following route categories: non-stop overlaps, one-stop overlaps and no overlaps (see Hüschelrath and Müller, 2013, for a detailed characterization). While non-stop overlaps are characterized by direct competition of both 
merging airlines in a particular non-stop airport pair, one-stop competition refers to the presence of a direct connection offered by one airline while the other carrier operates a onestop connection between the two airports. Although one-stop connections must be considered a low-quality substitute for a direct flight, it might still constrain the carrier with the direct flight in its price-setting behavior. For the HP-US merger, we have identified 4 routes with a non-stop overlap, 31 routes with a one-stop overlap (7 for US, 24 for HP) and 204 routes with no overlap (147 for US, 57 for HP).

\section{DATA}

Our dataset was constructed by collecting and merging data from several sources. We use airline traffic data for the years from 2005 to 2006 from the U.S. DOT T-100 Domestic Segment database. This data contains monthly domestic non-stop segment data reported by U.S. air carriers when both origin and destination airports are located within the boundaries of the United States and its territories. We use T-100's information on origin, destination, nonstop distance, available capacity, number of departures, and number of passengers to construct a quarterly panel data-set of non-directional non-stop route airport-pair markets. We drop airline-route observations with less than 12 quarterly departures and airline-route observations which were only served one quarter in the observation period. We add demographic information on the population and the number of establishments of the respective Metropolitan Statistical Areas from the U.S. Bureau of Labor Statistics.

\section{EMPIRICAL ANALYSIS}

For an assessment of possible entry-inducing effects of the merger, we estimate a model in which the dependent variable is the change in the number of carriers other than the merging parties ( $\Delta \#$ airlines w/o merger parties). Accordingly, we refrain from holding the number of other carriers constant but include the lagged value of this variable since the previous competitive environment should largely determine entry activity of other carriers after exit events. Table 1 reports the results of the fixed-effects regressions of merger's entry-inducing effects one year after the completion of the merger. 
Table 1: Fixed-effects regressions of merger's entry-inducing effects

\begin{tabular}{|c|c|c|}
\hline \multirow[b]{2}{*}{ Variable } & \multicolumn{2}{|c|}{$\Delta$ airlines w/o merger parties } \\
\hline & coeff. & (s.e.) \\
\hline post-merger & 0.005 & $(0.007)$ \\
\hline post \# direct comp. & 0.066 & $(0.090)$ \\
\hline post \# US route (no HP comp.) & $-0.035 * * *$ & $(0.012)$ \\
\hline post \# US route (HP one-stop comp.) & $-0.086 * * *$ & $(0.026)$ \\
\hline post \# HP route (no US comp.) & -0.009 & $(0.018)$ \\
\hline post \# HP route (US one-stop comp.) & $0.056 * *$ & $(0.027)$ \\
\hline \# airlines w/o merger parties (lag) & $-0.408 * * *$ & $(0.017)$ \\
\hline \# LCCs (lag) & $0.057 * *$ & $(0.029)$ \\
\hline ln(avg. plane size) & $-0.084 * * *$ & $(0.030)$ \\
\hline airport size (max) & $0.179 * * *$ & $(0.020)$ \\
\hline HHI of airport with larger size & $-0.234 * * *$ & $(0.071)$ \\
\hline airport siz (max) \# HHI of larger airport & $-0.114 * * *$ & $(0.024)$ \\
\hline airport size (min) & $0.238 * * *$ & $(0.037)$ \\
\hline HHI of airport with smaller size & $-0.245 * * *$ & $(0.067)$ \\
\hline airport siz (min) \# HHI of smaller airport & $-0.193 * * *$ & $(0.050)$ \\
\hline $\ln ($ population) (mean) & $-0.815^{* * *}$ & $(0.163)$ \\
\hline $\ln (\#$ establ. ) (mean) & $0.505 * * *$ & $(0.109)$ \\
\hline Year 2005 & $-0.010 * *$ & $(0.005)$ \\
\hline Year 2006 & -0.009 & $(0.009)$ \\
\hline Year 2007 & 0.001 & $(0.011)$ \\
\hline 2nd Quarter & 0.006 & $(0.004)$ \\
\hline 3rd Quarter & $-0.011 * * *$ & $(0.004)$ \\
\hline 4th Quarter & $0.011^{* *}$ & $(0.005)$ \\
\hline Constant & $7.076 * * *$ & $(2.000)$ \\
\hline Observations & & \\
\hline Routes & & \\
\hline $\mathrm{R}^{2}$ (within/between/overall) & 0.211 & 0.021 \\
\hline
\end{tabular}

As revealed by Table 1, we do not find an entry-inducing effect for all routes affected by the merger. The same result is found for the sub-set of routes in which both carriers competed on a non-stop basis pre-merger. However, on routes with one-stop competition, we do find a significant entry-inducing effect for HP routes with US one-stop competition but an entrydissuading effect for US routes with HP one-stop competition. On routes with no overlap premerger, we only find a small but significant entry-dissuading effect for routes operated by US.

The control variables largely show the expected behavior. The number of competitors (\# airlines w/o merger parties) has a negative effect on the change in the number of carriers 
other than the merging parties while the number of low cost carriers in a particular route (\# LCCs) is found to have a positive influence. Furthermore, a negative relationship is also found with respect to average plane size (ln(avg. plane size)) suggesting that the usage of larger airplanes dissuade entry. Turning from route-related to airport-related control variables, we also control for the influence of airport size as measured by the mean of the two endpoint airports' passenger share (airport size $(\max )$ ) as well as airport concentration (measured by the Herfindahl-Hirschman Index (HHI)). As revealed by Table 1, while the relationship between the change in the number of carriers other than the merging parties and airport size is found to be positive and highly significant, the respective coefficients for airport concentration show a clearly negative relationship. Furthermore, two demographic variables on the MSA level enter the analyses which aim to capture demand effects. The population (In(population force) (mean)) shall capture potential total demand. The number of establishments (In(\# establ.) (mean)) is included to capture the demand of less price-sensitive business people. As revealed by Table 1, while a positive relationship is found for the latter variable, population has a negative effect on the change in the number of carriers other than the merging parties.

\section{CONCLUSION}

We have investigated the entry-inducing effects of the America West-US Airways merger in the domestic US airline industry. Theoretical contributions suggest that mergers might attract new entry thereby foreclosing possibilities of the merged entity to increase prices postmerger. Our empirical results on an airport-pair route basis revealed that the entire merger did not have a significant effect on entry behavior by competitors. However, an analysis of different route categories revealed that routes which were operated by US Airways experienced entry-dissuading effects while routes operated by America West partly show a significant increase of entry activity by competitors. Interestingly, routes with ex-ante greater competition concerns (i.e., routes in which both merging parties competed directly before the merger) do not show increased entry activity. Our results therefore suggest that entryinducing effects should be treated with caution in merger assessments by competition authorities thereby supporting the key policy conclusions derived in Werden and Froeb (1998) from a theoretical perspective. 


\section{REFERENCES}

Cabral, L. (2003), Horizontal Mergers with Free-Entry: Why Cost Efficiencies May be a Weak Defense and Asset Sales a Poor Remedy, International Journal of Industrial Organization, 21, 607-623.

Hüschelrath, K., K. Müller (2013), Airline Networks, Mergers, and Consumer Welfare, Working Paper, Mannheim.

Marino, A., J. Zábojník (2006), Merger, Ease of Entry and Entry Deterrence in a Dynamic Model, Journal of Industrial Economics, 54, 397-423.

Spector, D. (2003), Horizontal Mergers, Entry, and Efficiency Defences, International Journal of Industrial Organization, 21, 1591-1600.

Werden, G., L. Froeb (1998), The Entry-Inducing Effects of Horizontal Mergers: An Exploratory Analysis, Journal of Industrial Economics, 46, 525-543. 